\title{
Protein Lin-52 Homolog
}

National Cancer Institute

\section{Source}

National Cancer Institute. Protein Lin-52 Homolog. NCI Thesaurus. Code C162420.

Protein lin-52 homolog (116 aa, $13 \mathrm{kDa}$ ) is encoded by the human LIN52 gene. This protein is involved in the regulation of G0 phase arrest. 